\title{
$\mathrm{Oz}$
}

Volume 20

Article 2

$1-1-1998$

\section{World-Time, Life-Time, and the Time of Architecture}

Karsten Harries

Follow this and additional works at: http://newprairiepress.org/oz

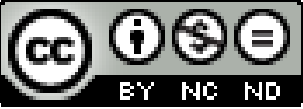

This work is licensed under a Creative Commons Attribution-Noncommercial-No Derivative Works 4.0 License.

\section{Recommended Citation}

Harries, Karsten (1998) "World-Time, Life-Time, and the Time of Architecture," Oz: Vol. 20. https://doi.org/10.4148/ $2378-5853.1313$

This Article is brought to you for free and open access by New Prairie Press. It has been accepted for inclusion in Oz by an authorized administrator of New Prairie Press. For more information, please contact cads@k-state.edu. 


\section{World-Time, Life-Time, and the Time of Architecture}

\section{Karsten Harries}

1. This year's issue of $\mathrm{Oz}$ "seeks to investigate the lasting qualities of architecture within our increasingly intangible society;" you summarize your "interests in this topic in a simple question with dual meaning: what gives a building substance in time"? Setting aside, at least for a while, "building" and "substance," let me begin with time, or rather with a statement made by Martin Heidegger: the authentic person, states Heidegger, "always has time." ${ }^{\text {How can }}$ that be? What could it mean to never be short of time? Even though often bored, with empty time on our hands, are we not continuously short of time? "Time," we say, "is money." We consider time a precious resource that can be wasted or put to good use and so we rush from one thing to another. How then can Heidegger say: the authentic person always has time? In the end will we not all run out of time, even though sun and moon will continue to rise and set, the seasons come and go, as will the grass, as will different generations? Can we take comfort from such repetition, from the sun's daily return and departure, from the ever returning seasons, from waves that beat on some ocean beach as they have always done? Does the ever 4 returning clatter of the washed up pebbles help us cope with the gap between the finite time allotted to us and the infinite time of a world indifferent to our desires, a time from which we will be excluded? How ephemeral and insubstantial are our lives.

2. Inseparable from the incommensurability of life-time and world-time is the terror of time. ${ }^{2}$ Vulnerable and mortal, we know about our mortality, know that all we are now, all that we can still be and will ever achieve, some day will be past. Time will take away all that we can establish. No building is substantial enough to stand up to time. And the more developed our sense of time's passing, the more oppressive this terror is likely to be, the more difficult we will find it to accept and affirm all that subjects us to time, first of all our inevitably aging bodies, our sexuality. Not that we moderns are the first to be visited by that terror. Our preoccupation with self and therefore with personal happiness and survival may have made mortality weigh more heavily, but the terror of time is as old as humanity. And as old as this terror are dreams of permanence and plenitude, of a realm time cannot ravage: true home of the

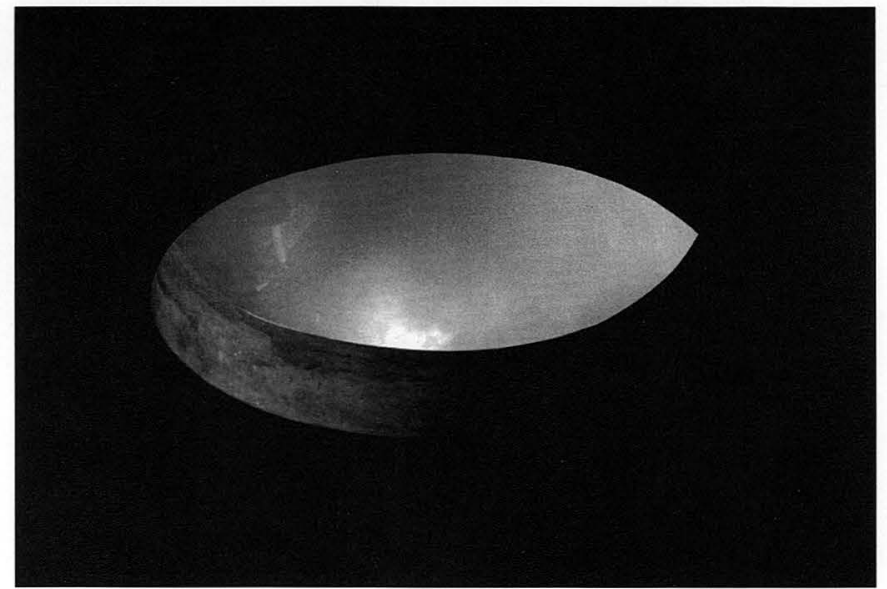

fig. 1. Langhorne Pavilion, Vieques, Puerto Rico, Ocolus. soul. And as old as this terror are attempts to build figures of that home.

Aesthetic experience has often been discussed as giving us a foretaste or semblance of such a homecoming. Plato set the theme when he thought beauty in opposition to destructive time and therefore also in opposition to materiality: beauty was linked to the spirit over which time has no power: the truth of the Pythagorean theorem transcends time. That beauty so understood should like to speak the language of geometry is not surprising. The pyramids can serve as a first paradigm. Still they testify to the death-defying victory of spirit over matter, even as their crumbling materiality calls that victory into question: substantial as they are, they, too, will not last forever; pure as they are, they are not pure enough not to be touched by time; for that they would have to leave materiality behind.

But even if we imagine them as giant crystals of some pure substance time could not wear away, such a utopian spiritual architecture could not shelter us mortals, would indeed be altogether insubstantial. And thus we learn: the substantiality of substance may not be 
thought in opposition to time. The German Wirklichkeithelps to remind us that the reality of the real resides in its ability to act or effect something (wirken), is bound up with time. The purity of pyramids, cubes, and spheres may thus promise deliverance from the terror of time, but that promise does violence to the substantiality of architecture, as it does violence to the whole human being. Shortchanged are earth, landscape, body, and individual. The space relevant to architecture is here understood, not as the space of lived experience, but as the infinite space of geometry. Into that space the architect casts his geometric figures.

Just because such architecture strives to become an expression of a spirit ideally unconstrained by gravity or matter, it needs to enter into an alliance with a technology able to bend earth and materials, landscape and site to what spirit demands. Modern architecture has thus been haunted by thoughts of a gravity-defying architecture built of some stainless super-material to be furnished by an ever advancing technology. Hence the fascination with buildings that look as is if they could be stood on their head, that do not belong to a particular landscape or history, with an architecture mobile in its very essence, if not mobile in fact. Much modern and also post-modern architecture is without place in the sense, not that it does, but that it looks as if it could stand anywhere, an architecture, we might say, in the subjunctive rather than in the indicative.

Le Corbusier's and even more Tatlin's love affair with flying machines belongs in this context. In the same spirit Van Doesburg demanded of architecture "a floating aspect (in so far as this is possible from a constructional standpoint - this is the problem for the engineer!) which operates, as it were, in opposition to natural gravity." Architecture here is to present itself as something it cannot be. In this connection Van Doesburg speaks, not of de-construction, but of counterconstruction. In his Counterconstruction of 1923 planes seem to float in an indefinite space, recalling Malevich's slightly earlier Suprematist compositions, which similarly float geometric shapes on a white background that figures the infinite void. Such ideas haunt structures like Rietveld's Schroeder House in Utrecht. In its utopian insubstantiality Mies van der
Rohe's Farnsworth House remains indebted to this tradition: striking the way the living space here seems suspended between two floating planes. Here, too, architecture veils its indicative with the subjunctive.

3. As old as the terror of time is the love of geometry: hence the perennial fascination with the Roman Pantheon and even more with its spherical soul. This domed ring of stone promises security, rest, eternal peace.

And yet this is not an altogether happy making space. Built in the image of the firmament, which the ancients thought a perfect sphere, a realm that knew neither death nor decay, connected to this realm by its cyclopic eye, this interior does not open itself to the human world or to the landscape. To be sure, we are reassured by the lightgranting oculus, by the vertical axis thus established, a would-be axis mundi, which seems to proclaim that we have arrived at the center. But shut out is that everyday world in which we are born, work, love, and die.

I called the Pantheon sublime. The sublime has long been linked to a sense of not feeling at home in this world, to dreams of an extramundane existence, of a freedom unconstrained by materiality, to the subjunctive. Such dreams continue to feed the post-modern fascination with the sublime as they feed post-modern attempts to de-construct all sorts of architectures. Sublimity and the requirements of building serving dwelling do not readily go together. A spherical house such as Ledoux envisioned seems a wooden iron.

The Pantheon, to be sure, is not a sphere. Still, the power of the sphere animates and spiritualizes this interior, transfigures it. And it is precisely this transfiguration that makes us forever strangers in this space: its center is one that we can literally occupy only in spirit, not in body. The clarity of the geometrical idea banishes the terror of time at the price of a fuller humanity. To affirm ourselves, we have to affirm our temporality, and that means also our materiality, our mortality. In this timedefying interior ongoing life seems to have little place, and it is hardly surprising that the Pantheon's first successors should have been tombs. There is indeed something deadly about its stony geometry. Its eternal order 


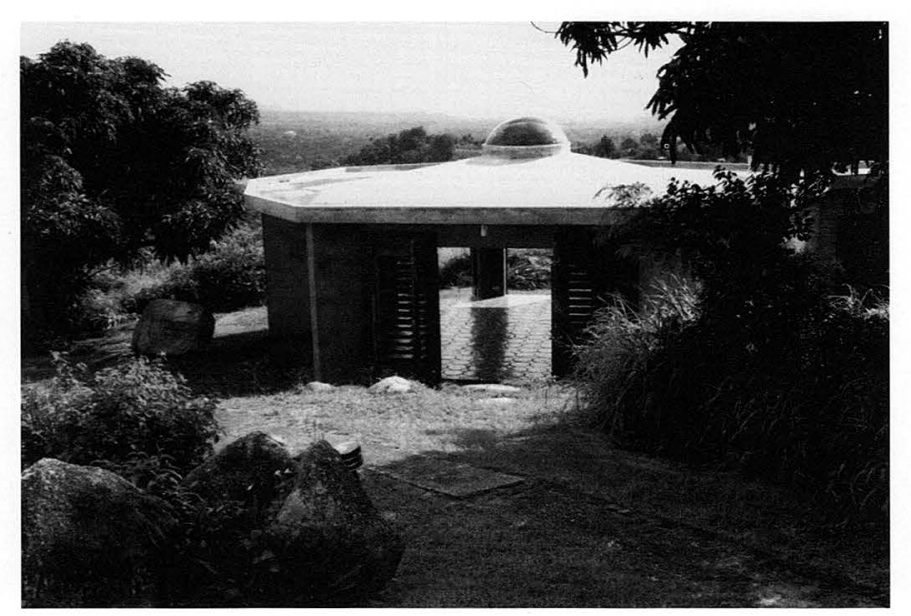

fig. 2. View to the east.

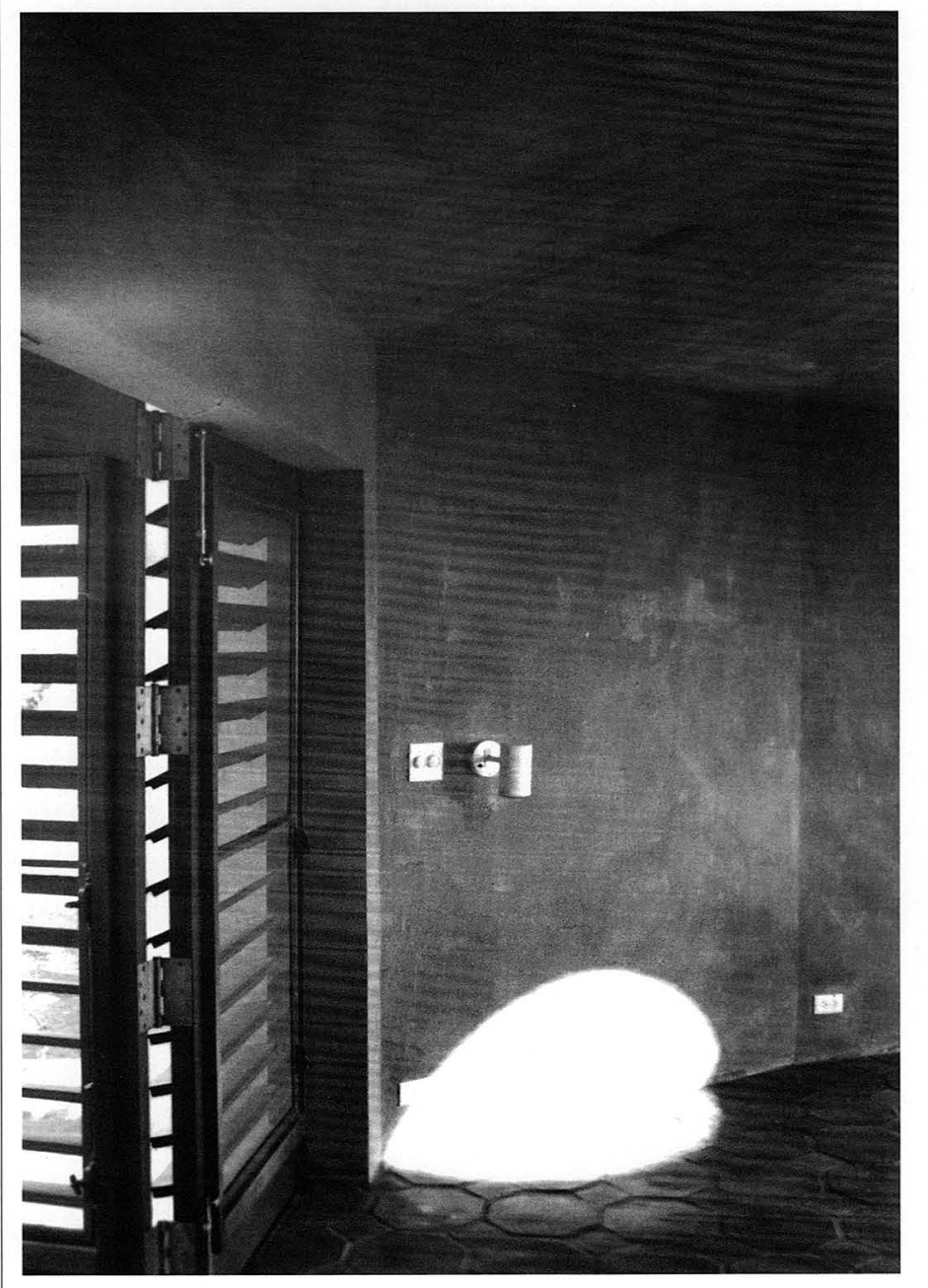

6 fig. 3. Interior with sun spot. seems indifferent to life on earth; its spiritualized light does have the power of transporting us, as our everyday cares and concerns are bracketed: in time we are given a fleeting deliverance from the burden of time, a semblance of redemption. And so understood the Pantheon's Platonic beauty figures the redemptive power of an art that rather than celebrate life would deliver us from life's burdens, that would let us live as if no longer alive. So understood the Pantheon's cold beauty, this symbol of eternal plenitude, also figures death.

4. But consider once more the Pantheon's oculus, this window to what the ancients thought a realm unblemished by death. The oculus also literalizes the Platonic definition of time as the moving image of eternity, allowing the changing times of the day and the year to animate this interior, attuning this built cosmos to the cosmos.

My wife and I learned to experience the calming power of a similar if, of course, much smaller oculus (fig. 1) in a concrete pavillion for work and sleep that we built on the island of Vieques near Puerto Rico (fig. 2). A light Buckminster Fuller type dome had stood on that site, its pure geometry no match for Hurricane Hugo, which lifted it off its base and set it literally afloat, sent it sailing downhill, as if it were a frisbee, leaving us a clean swept tile floor, still standing on it an unscratched bathtub and a toilet. On that foundation we raised our pavillion, now of heavy concrete, grey and substantial, like the rocks scattered on that hilltop. It was our architect, Edward F. Knowles, who convinced us to open this modest interior to the sky. I had at first wanted a folded tent-like ceiling, its facets to be animated by an ever-changing indirect light. But now, like the Pantheon, this space functions conspicuously as a sun, moon, and star-dial, mediating life-time and world-time (fig. 3). I find it reassuring to wake up at night and glimpse some part of Scorpio or Orion overhead, even a shooting star, to follow the moon tracing the passing hours on floor and walls.

And yet, were there just this oculus, this small decagon would be a disturbing, suffocating space. The vertical thus established demands the horizontal. The space demands to be opened, not just to the sky and its changing light, but to the surrounding landscape, especially to the 
east (fig. 4). In the morning especially one welcomes the quickly intensifying light poured in by the rising sun, reflected by the now orange-red, cement-tile floor, painting the grey walls a soft pink, filling this space, which becomes a chalice ready to receive, not just the gift of light, but also of life, noisily announcing itself as cocks begin to crow, dogs begin to bark, a car rumbles on the road below, distant humans begin to work. This active light activates the whole building, makes it more substantial.

What is it then that gives a building substance in time? Perhaps our modest little pavillion hints at an answer: the presencing of time.

What matters is not so much that heavy reinforced concrete now replaced wood vulnerable to termites, but rather how the building marks and allows itself to be marked by time. To re-present this process, so very much part of the life of this landscape, we chose not to paint the concrete, to leave it, both inside and outside, with all its blemishes, spots and stains, leave it to change as the building begins to age, celebrating the way buildings, too, have a mysterious life of their own (fig. 5). They, too, stand in a temporal context, gain strength and substance from re-presenting it. We therefore welcomed the way the simple plan preserves something and reminds us of the dome swept away by the storm-in fact we still call our pavillion "the dome:" the building's prehistory helps to render it somehow more substantial.

What matters is the way it embraces the landscape, the way it seems to have found its place on this hard to work earth, among the grey rocks, between two mango trees; the way the roof collects the water of quickly passing showers, sending it on to the cistern; the way the interior opens out to the landscape, to the time of this landscape, marked by the sun, rising and setting,

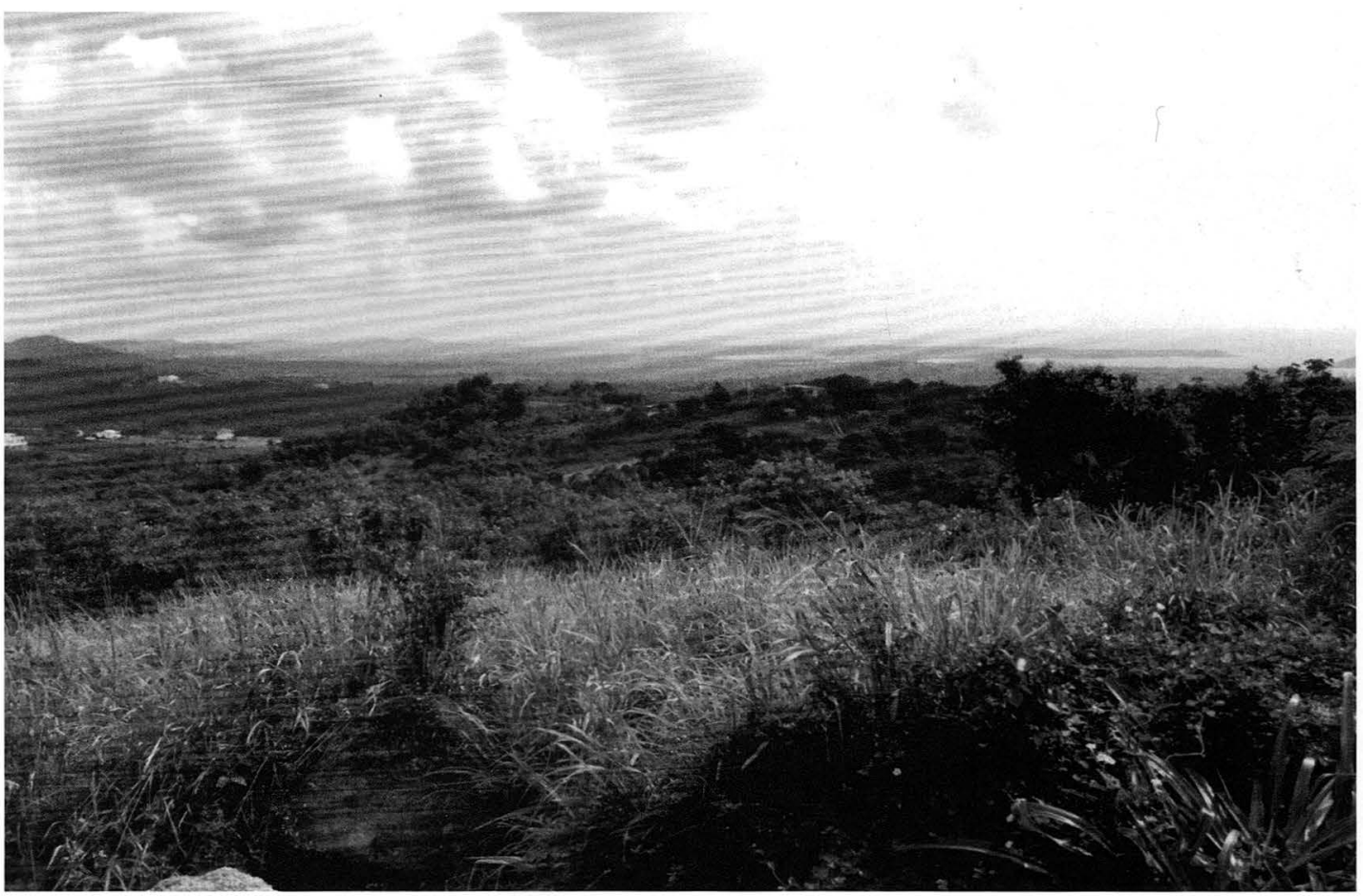

fig. 4. Looking east. 


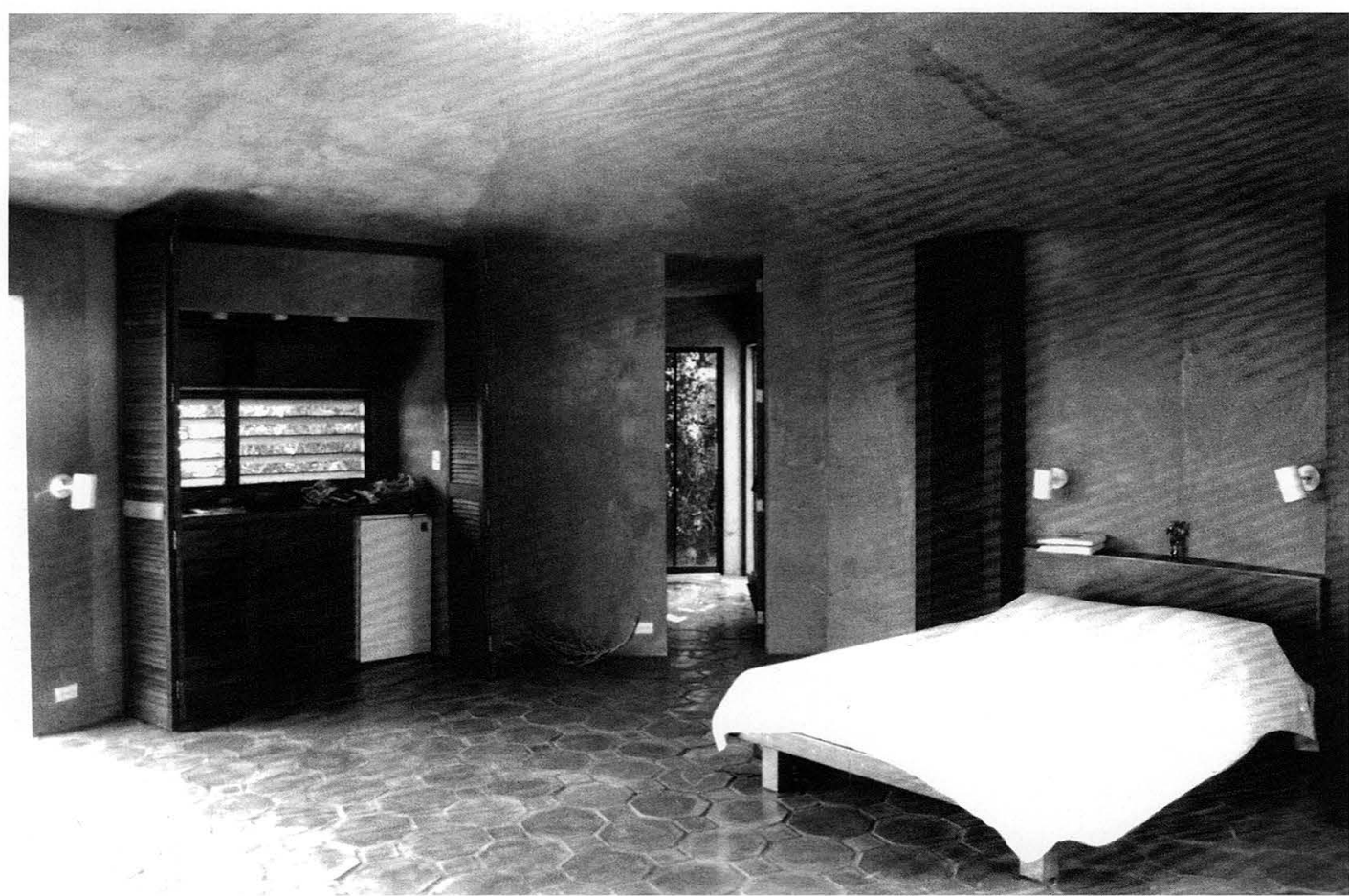

fig. 5. Interion. by the repeating rhythm of light and dark, by the rhythms of growth and decay, of birth and death. Such buildings teach us not to take ourselves too seriously (fig. 6).

5. What gives a building substance in time? That could be taken to mean: what allows a building to stand up to time, and here one might think of the Vitruvian commandment that the architect build "with due reference to durability, convenience, and beauty," where durability is mentioned first. Buildings should last—and last the pyramids and the Pantheon certainly did. They were well built. And we hope that our little pavillion will stand for many years. The question "what gives a building substance in time?" here received a ready answer: reinforced concrete! So understood the substance of architecture is thought against time and readily represented by lasting materials and the ageless beauty of geometric forms, is thought in the image of the cosmos created by the demiurge in Plato's Timaeus.

But such durability and seemingly timeless beauty, even as they gesture towards a plenitude untouched by time, cannot provide us mortals with substantial homes. Such homes require us to think the substance of buildings not against, but with time. And somewhat unexpectedly it is Plato, who taught us to think beauty against time, who also calls the one-sidedness of such thinking into question. In the Symposium he thus not only lets Socrates define beauty as the object of love, love as a desire for a plenitude denied to us by our temporality, a plenitude that demands eternity, but also challenges that definition. Diotima, the wise woman from Mantinea, corrects the young Socrates: "The object of love, Socrates, is not as you think, beauty,... Its object is to procreate and bring forth beauty." A time-bound, procreative eros is here opposed to an eros content in the contemplation of pure beauties. So understood, full self-affirmation requires 


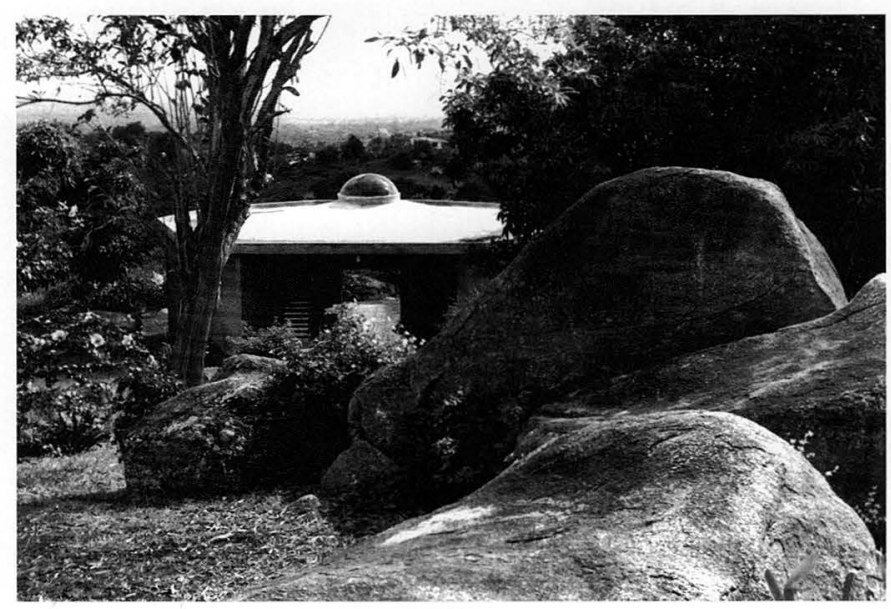

fig. 6. View to the east.

not only that we humans open ourselves to eternity and to that in us which allows us to think and dream of eternity, but equally that we affirm our mortality and in time cast ourselves beyond ourselves. Such self-affirmation demands a certain selflessness, demands that we renounce all attempts to seize dreams of god-like plenitude, the kind of plenitude figured by the sphere and in Plato's Symposium by Aristophanes's circle-men, of which we in our present condition are said to be but halves, in search of the lost whole. Much as dreams of plenitude figured by circle and sphere may haunt us, all attempts to realize such dreams, to become substantial in this sense, will end up making us less substantial, more ghostly-and something analogous holds for architecture.

6. The Book of Revelation says of the devil: "he knows that his time is short." Are we then, especially we moderns who, while trying to kill time, are ever short of time, rushing from one thing to the next, not of the devil's party? As long as we cannot forgive ourselves our temporality, and that means also, as long as we have not found in time a friend rather than a tyrant, have not mastered the art of dying, we will also be unable to accept ourselves as we are, embodied, vulnerable, and mortal, will find it hard to take pleasure in whatever reminds us of the passing of time, will find grating the clatter of the pebbles washed up by the waves, the chatter of small children, killing, not only time, but ourselves by keeping busy and amused.

"The authentic person always has time." Can architecture helps us to "take time" in such a way that we will "always have it"? The answer cannot lie with an architecture built to protect us from time but rather with an architecture built to place us in time and thus to return us to ourselves; not then with buildings that seek to answer the terror of time with the timeless beauty of geometry and lasting materials, but with buildings that make room for time.

Appealing to the etymology of bauen, Heidegger invites us to think building as a way of cultivating the earth. Proper cultivation takes time, as I learned when, still a child, I visited with my now dead father Germany's Spessart mountains known for their old oaks. I remember him telling me that these trees were planted with the expectation that they would be "harvested" hundreds of years later. Not overly concerned with their individual life-spans, those who planted them were willing to take their time. Long gone are these oak-planters: did they run out of time?

All photos by the author.

Notes:

1. Martin Heidegger, Sein und Zeit, 7th ed. (Tübingen:Niemeyer, 1953). p. 410. 2. Cf. Hans Blumenberg, Lebenszeit und Weltzeit (Frankfurt: Suhrkamp, 1986). 3. Theo van Doesburg, "Towards a plastic architecture," Programs and manifestoes on 20th-century architecture (MIT Press: Cambridge,Mass., 1971). p.79. 